\section{FURTHER NOTES ON THE NORTHERN ARMY WORM.}

HOW FAR IS BURNING OVER A PREVENTIVE

That fields which have been burned over in the winter are free from the destructive presence of the worm is a fact in the history of its visitations. But opinion has varied as to shown that it destroys the appropriate nidus for the laying of the eggs by the moth in the spring. Now that larval hibernation is established, we can readily see that the fires hibernation is established, we can readily see that the fire
would destroy these hibernating larvæ and prevent the appearance of the moths and of a second destructive brood from them. But we must not suppose that the burning over would prevent all appearance of the worm; it merely prevents its appearance in destructive numbers. The moth concealment and upon plants, such as clover, which the larva does not relish.* In such sases of excer, which the dance we may well suppose that the moth will fy into fields which had been burned over and supply them with eggs, but the instances in which this would result in material damage to the crop would be very rare.

$$
\begin{aligned}
& \text { CONNECTION OF WET AND DRY SEA } \\
& \text { WORM INCREASE. }
\end{aligned}
$$

That the army worm appears in destructive numbers after a period of $\boldsymbol{d r y}$ seasons is a fact already recognized, and is in accordance with the experience of the present year. The portions of our country visited by the worm this year were afflicted with drought last summer, and the winter was reafflicted with drought last summer, and the winter was re-
markable for its mildness and the slight fall of snow. markable for its mildness and the slight fall of snow.
Fitch's theory of the appearance of the worm require that this spring should be a wet one in order to drive the moths from the swamps and cause them to lay their eggs on the upland. But the facts are just the reverse. Farmers from Virginia to Vermont have complained loudly of the exces sive drought. Rivers in some of the Atlantic States have not been so low for a generation, and alluvial meadows which have been subject to a spring flooding have this year remaine dry. These facts clearly disprove Fitch's theory, and we must believe that the army worm is most likely to appear after dry seasons, regardless of the wetness or dry ness of the season in which it occurs. A critical examina tion of Fitch's arguments in support of his theory shows that he not only had no personal acquaintance with the
worm, but also made some astonishing errors in meteorology, such as comparing the rainfall of India (?) with the appearance of the worm here. With equal reason might we the excessive precipitation in the British Islands during that year. It is evident that Fitch was hard pressed for arguments to support the theory. That the season of 1861 was remarkably wet in the Eastern States Fitch gives no evi-
dence. From the well known connection of the presence of dence. From the well known connection of the presence of
plant lice with dry seasons, and from the memorable depredations of the grain aphis in that year throughout the Middle and New England States, it is very questionable whether 1861.was wet. It is far more probable that the season was have done great damage.

The view that the army worm has its proper home in the wild grasses in the swamps, as Fitch has assumed, must also be considered erroneous. The moth prefers matted grass amid which to lay its eggs, and the more tender grasses are those first selected by the worms. Old neglected fields, whether their location be low or high, are the most natural breeding places for the insects. That the worms most of ten appear in low lands, or in the neighborbood of such, doubtless finds more correct explanation, first, in the highly food at such places, either in saccharine exudations, the natural "sweat" of the plants, or moisture from the ground; secondly, in the well observed fact that such lands afford the greatest extent of neglected meadows where the insect has opportunity to multiply unnoticed and undisturbed.

\section{Dangerous Freight.}

A case marked "benzine" or "benzoline" exploded with terrific force on the Pacific Steam Navigation Company's steamer Coquimbo, at Valparaiso, recently. A breach nearly twenty feet in length was made in the side of the vessel, for tunately above the water line. One man was killed. The immediate cause of the explosion is not given. The carrying immediate cause of the explosion is not given. The carrying the too frequent disappearance of ships at sea.

\section{American Ironware in New Zealand.}

A former resident in Birmingham, England, writes from New Zealand: "I was much interested in noticing how your staple trades were represented here. One article your town stands unrivaled in-lamps; but in every other branch
of the hardware trade the vigorous Yankees beat you. In agricultural and gardering implements, stoves, domestic notions, and the thousand and one articles of hardware, $\mathrm{En}$ glish makers are nowhere here. For quality, adaptability, and price, the American articles bear the palm. I was one day in the store of one of our leading hardware merchants,

* I have recently received from Professor Lintner, State Entomologist for New York, what are apparently the pressed eggs and egg shells of this moth, thickly covering clover leaves, and mixed with an abundance of
white gummy matter with which the moth usually secretes them, all in

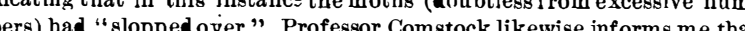
he has found the eggs laid between the folded lobe of a clover leaf.

when a miner came in for a pick and shovel. He was asked his sole proprietorship where it was denied by the other which he would look at, English or American. 'Oh, Yan- party. I have no doubt of the soundness of this opinion. kee tools for me,' said the man; 'English are too clumsy.' : But certainly if this were not the case it ought to be clearly

My friend explained that the English will persist in makin

\section{DECISIONS RELATING TO PATENTS.}

U. s. Circuit Court-Northern District of minois. TTLESE $e t$ al. $v s$. AMES $e t$ al. SAME vs. ZIMMER
SAME ws. DEAN.-PATENT BEDSTEAD FRAMES.

Blodgett, J. :

Reissued letters patent No. 7,704, dated May 29, 187\% or an improvement in bedstead frames, declared to be for he invention embrace in the original patent, granted No
vember 30,1869 , and claims 1 and 2 thereof construed, in iew of the prior state of the art, and sustained.

2. A patent will not be defeated by evidence of prior simiar devices which were of an experimental character simply nd which were susequently destroyed.

3. Although the efforts of prior unsuccessful experimenters may have suggested to the patentee the construction which he finaily adopted and perfected, and may have been of profit to him as far as they went, his patent will not be invalidated thereby.

\section{By the Commissioner of Patents.}

RS-IN-CHIEF.-INTERFERENCE. -PIPE TONGS.

Marble, Commissioner:

1. Where a patent has issued to two or more persons a oint inventors, and an application is subsequently made by ion, an interference will be declared, and the question of priority of invention will be determined by the weight of
evidence, the burden of proof being upon the sole applicant the overcome not only the testimony of his adversary bu lso his own former oath of joint invention.

2. The right of the sole applicant to a patent, where the by the mere denial by his co-patentee of the fact of sole in ention.

3. The decisions of the Commissioner in the case of De
Lill vs. Avery \& De Lill (C. D. 1870, p. 128) and the case Chase and White vs. Chase (C. D., 1873, p. 99) commented pon.

Application of C. H. Lovrien, filed August 14, 1879 Patent No. 213,376 grar
ien, March 18, 18:9.

On February 10, 1879, Henry Banister and Charles H. Lovrien made an application as joint inventors for a patent
or an improvement in pipe tongs, and on March 18, 1879, a atent was granted to them.

Charles H. Lovrien, one of the joint applicants and atentees, on August 14, 1879, filed an application as sole in ventor for a patent for the invention already patented to him-
elf and Banister jointly, and on September 16, 1879, an in self and Banister jointly, and on September 16, 1879, an inerference was declared between Lovrien, sole.
part and Banister and Lovrien upon the other.

It is contended on behalf of Lovrien that the entire inven. tion embrace in the patent and in this application was made y him alone; that he desired, however, that Banister, for a consideration, should have a half interest therein, and that by reason of his own ignorance of patent matters he allowed
Banister to attend to the procuring of the patent, and supposed that the joint application, which he claims not to have
carefully considered, simply secured to Banister his interest. carefully considered, simply secured to Banister his interest.
Banister, on the other band, claims that the invention was a joint one, and that it was so regarded by Lovrien at the time the joint application was made. The Examiner of Interferwhile the Board of Examiners-in.Chief favor of Lovrien, Lovrien to be joint inventors of the matter at issue, and de ided in their favor.

The question to be determined in the case is clearly one of originality rather than of priority of invention. It is urged
by counsel for patentees, and such appears to have been the ground taken by the Examiners-in-Chief, that where a patent has issued to joint applicants, and a sole application for the same invention is subsequently made by one of them, a patent cannot issue upon such application if the fact of sole invention is denied by the other party. Two decisions are
cited in support of this position. In the first of these (the ase of De Lill vs. Avery \& De Lill, C. D., 1870, p. 128) the fllowing language occurs:

"It is a matter of gra

"It is a matter of grave doubt whether one who joins nder his signature, verified by his oath, to be the joint troduced by Banister to show that Lovrien regarded him as production of himself and his co-applicant, ought ever be a joint inventor, and that he carefully considere and fully permitted to deny that oath and seek a sole patent. It understood the joint application before the same was filed. would appear that a sound public policy would require that This testimony, however, is not of a conclusive character he should suffer the consequences of his mistake, even if and is far from sufficient to overcome the direct and otherit be innocent. But however this may be, it may be stated wise uncontroverted testimony of the several witnesses inas a rule that wherever the facts are disputed the joint pa troduced by Lovrien to show that he had completed and tent will not be disturbed. In the present case the burden of disclosed to others the invention prior to his meeting wit 'proof is of course upon De Lill to show that he was the Banister, and which is fatal to the latter's claim as joint in He inventor of the improvement covered by the joint patent. ventor. The weight of evidence is, in my judgment, clearjy
Hevercome his own oath, which cannot be treated and conclusively in favor of Lovrien, and shows, beyond any He must overcome his own oath, which cannot be treated and conclusively in favor of Lovrien, and shows, beyond any reasonable doubt, that he had completed the invention long
In the subsequent case of Chase and White vs. Chase (C. D., prior to his meeting with Banister, and such work as was 1873, p. 99), Mr. Commissioner Leggett, in commenting upon done by the latter was but that of a mechanic and not of an the above decision, said:

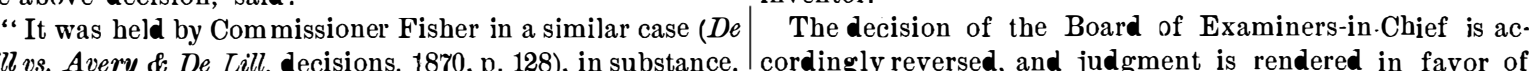
that a party to a joint patent was estopped from asserting Charles H. Lovrien. 